\title{
The 1987-88 surge of West Fork Glacier, Susitna Basin, Alaska, U.S.A.
}

\author{
W. D. HARrison, K. A. Echelmeyer, \\ Geophysical Institute, University of Alaska-Fairbanks, Fairbanks, Alaska 99775-0800, U.S.A.
}

\author{
E. F. CHacho, \\ U.S. Army Cold Regions Research and Engineering Laboratory, Fort Wainwright, Alaska 99709, U.S.A.
}

C. F. RAYMond AND R. J. BEnEdict

Geophysics Program AK-50, University of Washington, Seattle, Washington 98195, U.S.A.

\begin{abstract}
A surge of West Fork Glacier, a temperate glacier in the Susitna Basin of the Alaska Range, began soon after the end of the 1987 melt season and terminated on 6 July 1988. Reconnaissance measurements of balance, elevation and speed had been made from 1981 to 1983. Daily measurements of surface speed at two points $9 \mathrm{~km}$ apart and of the characteristics of the stream draining the glacier were begun during the surge and continued through the following year. The maximum displacement of the ice during the surge was about $4 \mathrm{~km}$; the maximum change in surface elevation was about $120 \mathrm{~m}$. Between the time of the start of detailed observations on 12 February 1988 and the onset of a complex termination phase during the last month of the surge, the speed was almost constant, and the water discharge was totally free of turbidity, indicating that no basal water was escaping from the glacier. During the termination phase, sharp changes in speed occurred, almost simultaneously at the two observation sites; each deceleration event was accompanied by high sediment concentration and high water discharge. This behavior is similar to that observed on Variegated Glacier during its 1982-83 surge. The mechanism of triggering (related to surface water input and the disruption of the internal drainage system) and the cause of the fast motion were probably the same for both surges, even though there are substantial differences in size and mass-balance characteristics.
\end{abstract}

\section{INTRODUGTION}

At the end of the 1987 melt season, West Fork Glacier in the Susitna River Basin, one of the larger glaciers in the Alaska Range, began a surge which lasted about 10 months. The changes in the glacier, although spectacular, were probably not unusual for this type of event, but the surge presented us with an unusual opportunity. First, we had carried out a reconnaissance study of the balance, dynamics, geometry and history of the glacier several years earlier, from 1981 to 1983 , and a background of data on the sediment regime in the Susitna River, into which West Fork Glacier drains, had been acquired by others. Secondly, the timing of the surge commencement was constrained by aerial photography. Thirdly, we were able to mobilize resources from other projects to begin daily glacier and hourly river observations during the surge. These circumstances combined to produce the first detailed data from a large surging glacier and an assessment of the effect of a major surge on a large river, Susitna River, which drains the basin.

This paper is focused on the observed changes in glacier geometry and speed, and their comparison with observations of other surge-type glaciers. Some of the observations made in the stream near the glacier terminus are included for comparison with the measured speed, but a detailed description of the stream measurements, and of measurements made downstream in the river, will be given separately.

\section{WEST FORK GLAGIER}

\section{Description}

West Fork Glacier is in the Susitna River Basin on the south side of the central Alaska Range (Fig. 1). Several other well-known surge-type glaciers (Susitna, Black Rapids and Yanert Glaciers) and others which appear to be intermediate between "surge-type" and "normal" (such as Maclaren and Eureka Glaciers) are nearby (Post, 1969; Mayo, 1978; T. S. Clarke, 1991). All the surge-type glaciers are confined to the central and southern parts of the range in this area, and all are relatively large; West Fork Glacier has a length of about $40 \mathrm{~km}$, an area of about $257 \mathrm{~km}^{2}$ and an average width of about $3 \mathrm{~km}$. The 


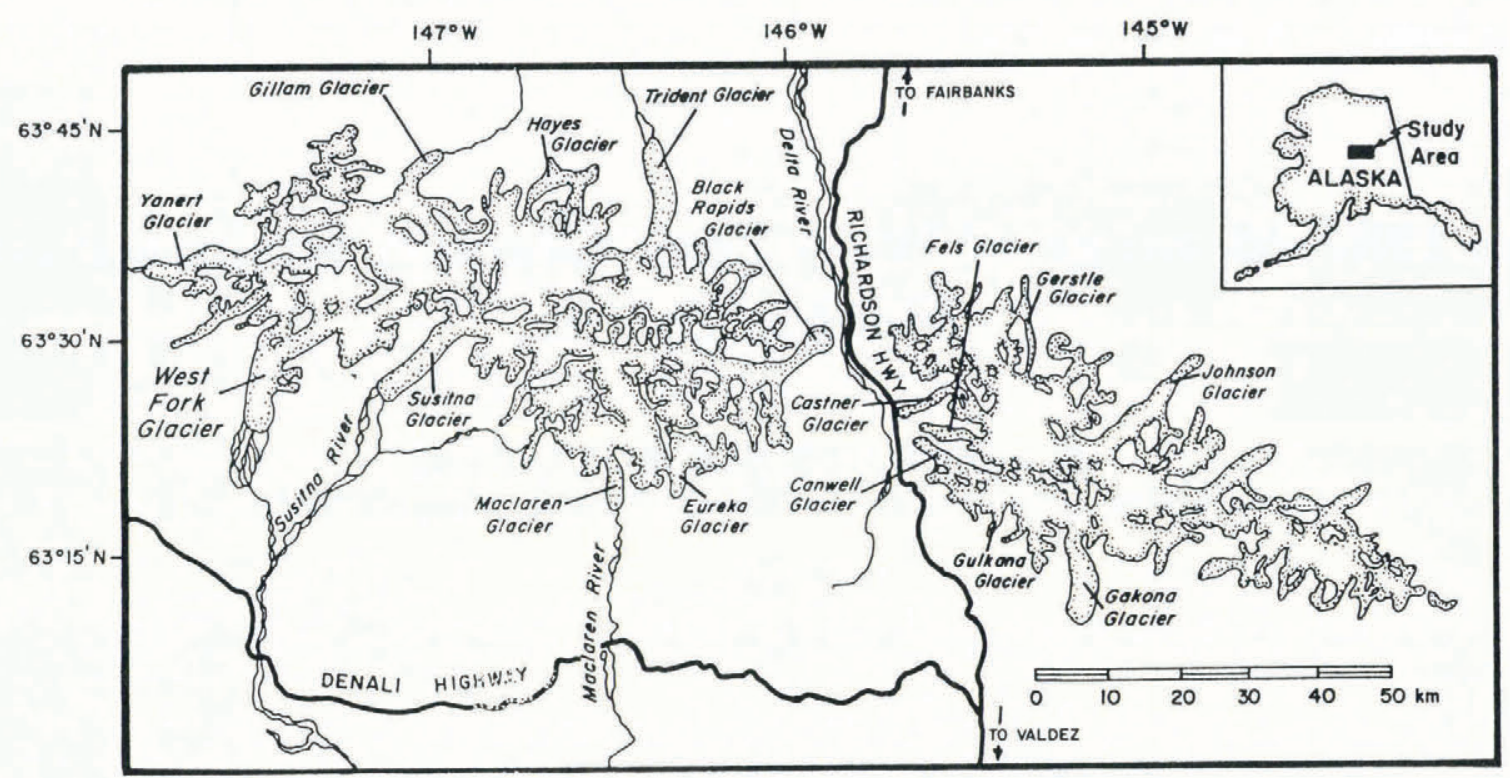

Fig. 1. Location map. West Fork Glacier is to the left.

average surface slope is about $1.5^{\circ}$ over the part of the main trunk which surged.

West Fork Glacier is shown in more detail in Figure 2. It has two major tributaries ( $\mathrm{A}$ and $\mathrm{B}$ ) and two major accumulation basins. Figure 2 is taken from U.S. Geological Survey maps, which are based on 1949 photography. It therefore portrays conditions then, except that we have shown a lake, which was absent in

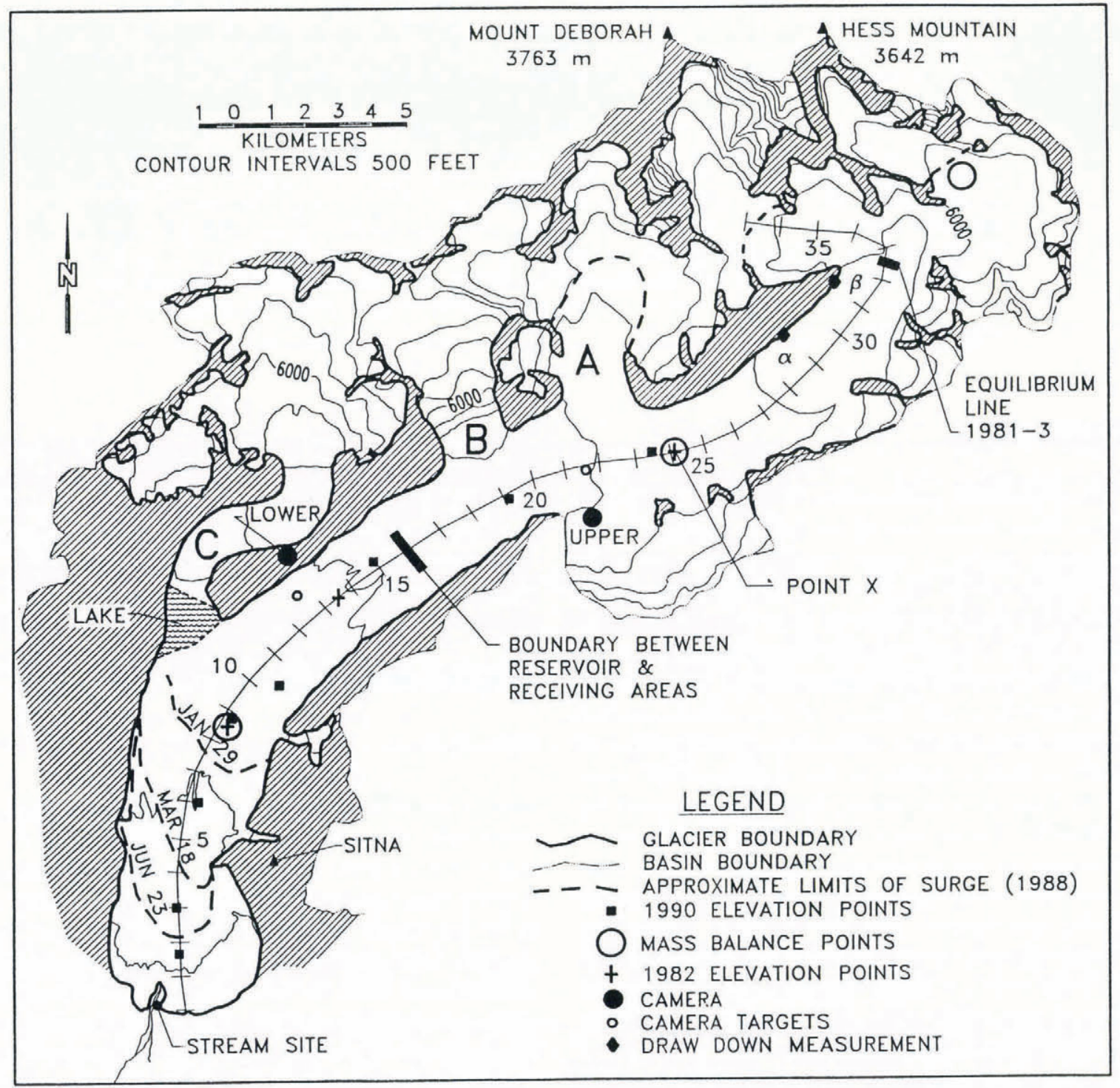

Fig. 2. Map of West Fork Glacier. Elevations are in feet $(1 \mathrm{ft}=0.305 \mathrm{~m})$. 
1949 but formed during the recent surge, between the main trunk of the glacier and the glacier labelled " $C$ ". Glacier C, probably a tributary of West Fork Glacier in the recent past, now calves into this lake. Figure 2 includes a longitudinal coordinate system, drawn up the center line and labeled at $5 \mathrm{~km}$ intervals, to which all measurements are referred. The zero is taken at the lowest terminal moraine shown on the map, which has been unaffected by the last two surges.

Before the surge, the surface of West Fork Glacier was not heavily crevassed, but was pitted with shallow holes as can be seen in Figure 3. These holes, called "potholes" by Sturm (1987), or "lacunas" by A. Post, seem to be characteristic features of some surge-type glaciers in Alaska and Yukon Territory. Those on the nearby Black Rapids Glacier (Fig. 1) often partially fill and drain, even in winter (Sturm and Cosgrove, 1990). Those on West Fork Glacier are unusual in that they occur far down into the ablation area; they are usually clustered near the equilibrium line (Sturm, 1987). Many of them were still identifiable after the surge.

\section{Geologic setting}

The geologic setting of West Fork Glacier is complex (Fig. 4). The strike-slip McKinley Strand of the Denali Fault System underlies the glacier for much of its length above $15 \mathrm{~km}$ (Sherwood and others, 1976; Brewer and Craddock, 1989). North of the McKinley Strand is the Aurora Peak Terrane which consists of schists, quartzite, and

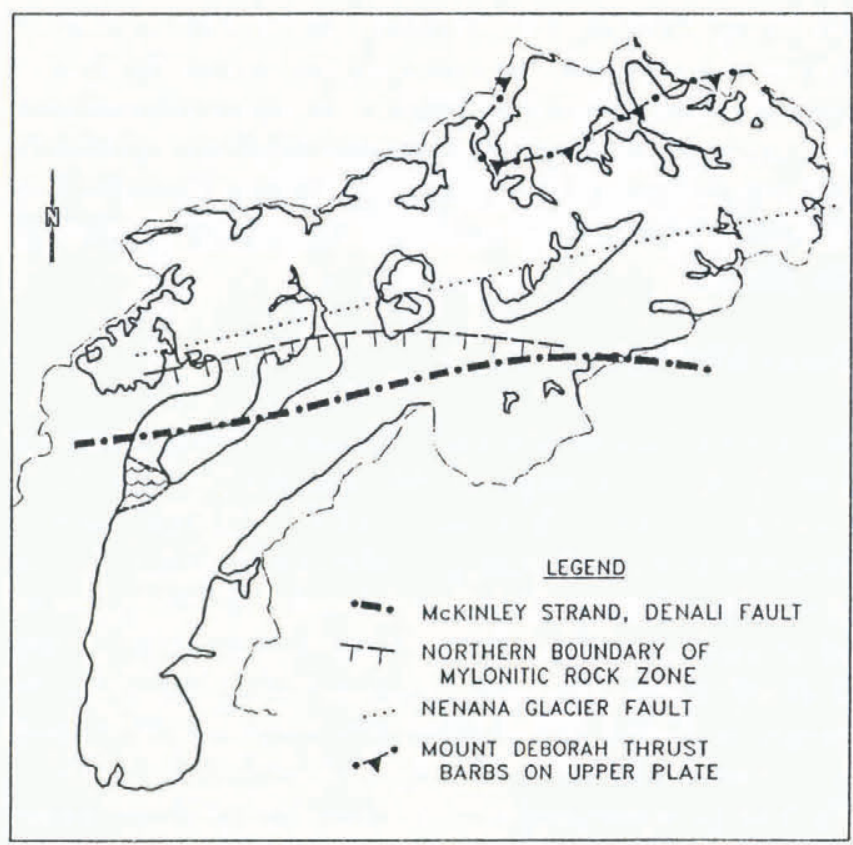

Fig. 4. Geologic boundaries in the vicinity of West Fork Glacier.

amphibolites of Cretaceous-Tertiary age intruded by Tertiary granitic plutons; to the south is the Maclaren Terrane which also consists of Cretaceous-Tertiary metamorphic rocks, including greenschists, pelitic schists and gneiss. A band of mylonitic rock lies north of the

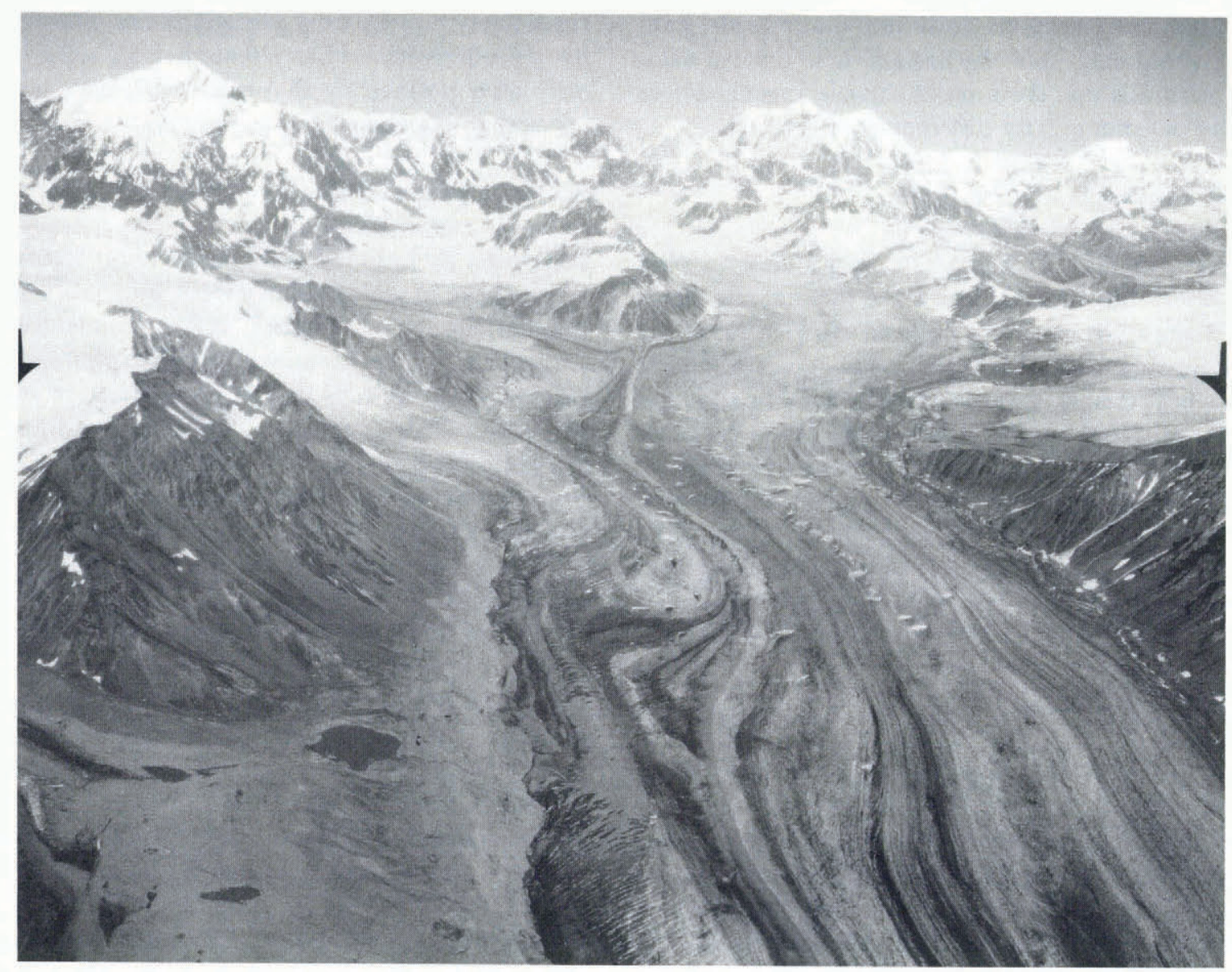

Fig. 3. Photograph of West Fork Glacier on 25 August 1987, near the beginning of the surge (R. Krimmel and A. Post, U.S. Geological Survey, photograph \#87R3-197). 
McKinley Strand. The Nenana Glacier Fault, another strand of the Denali Fault System, cuts across the glacier near the equilibrium line. High in the accumulation area are outcrops of Mesozoic-Paleozoic phyllites, quartzites and conglomerates belonging to the Windy Terrane. The Deborah Thrust Fault underlies the uppermost part of the glacier.

\section{Surge history}

West Fork Glacier was first identified as surge-type by Post (1969). Its surge history has been studied and summarized by T.S. Clarke (1991). On the basis of evidence from a photograph taken by B. Washburn in July 1940 (\#2814), Clarke concluded that the previous surge took place about 1935 , or about 52 years before the 1987-88 surge. He also found moraines from earlier surges in NASA U2 photographs taken on 29 August 1981 (line 85, \#5412 and 5413), and concluded that the c. 1935 surge terminated about $1.1 \mathrm{~km}$ farther down-valley than the recent one.

\section{Balance}

Balance measurements were carried out on West Fork Glacier from 1981 to 1983 at three points shown in Figure 2 , which at that time were situated at elevations of about 980,1430 and $1950 \mathrm{~m}$, respectively. The results have been summarized by T. S. Clarke (1986). Averaged over the 3 years, the annual balances at these points were about $-4.1,-1.4$ and $2.0 \mathrm{~m}$ (water equivalent), respectively, and imply an equilibrium-line elevation of about $1620 \mathrm{~m}$ then. (Small elevation corrections have been made to the data in Clarke's summary.) On the basis of these limited data, Clarke concluded that the annual balance averaged over the glacier was not greatly different from zero.

\section{Thermal regime}

No temperature measurements have been made on West Fork Glacier, but measurements on the nearby Black Rapids Glacier (Harrison and others, 1975) and on the adjacent Susitna Glacier (see Fig. 1) suggest that West Fork Glacier is temperate, at least below $2350 \mathrm{~m}$ elevation (T. S. Clarke, 1991). A cold near-surface layer probably exists in the ablation area. However, the picture may not be so simple, because some of the snow accumulation takes place at elevations up to $3700 \mathrm{~m}$, where little melting is expected. It is possible that the resulting cold ice may be transported to much lower elevations before it is warmed to near $0^{\circ} \mathrm{C}$.

\section{Speed before the surge}

Several years before the surge, from 1981 to 1983 , speed was measured at point $\mathrm{X}$, located at a longitudinal position of $24.2 \mathrm{~km}$ (Fig. 2). The results have been summarized by T. S. Clarke (1991). The speed showed a strong early summer maximum; the lowest measured value occurred in late summer. This behavior is common to the other major glaciers in the basin and to many glaciers elsewhere. The July 1981-June 1983 average speed was $62.2 \mathrm{~m} \mathrm{a}^{-1}$. An interesting observation was that the annual speed showed an increase of about $20 \%$ from $1981-82$ to $1982-83$.

\section{SURGE INITIATION AND GHARACTERISTICS}

\section{Initiation}

Soon after the 1981-83 studies of West Fork Glacier, T. S. Clarke (1986) noted that if its surge period is similar to that of the neighboring Susitna Glacier (which he had determined), "a surge may be expected fairly soon". This conjecture turned out to be correct. R. Krimmel and A. Post (U.S. Geological Survey), during an observation flight on 25 August 1987, noticed new crevassing on the glacier surface, and suggested, in an internal U.S. Geological Survey memorandum summarizing their aerial observations for the year, that a surge was beginning or was imminent. Figure 3 is one of their photographs. The surge may well have been beginning at the time of this photograph, although the possibility that the crevassing was due to some precursor event cannot be excluded. At any rate, large displacements had not yet occurred, because the margins were still relatively unsheared and the surface relatively uncrevassed. On 5 January 1988, while flying on another project, we independently discovered that a major surge was in full swing by then, as indicated by the sheared margins, crevassed surface and surge front.

Unfortunately, the observations do not determine the region where the surge was initiated. We speculate that it was either distributed (rather than localized) or else spread very rapidly from a localized site. This is suggested by the observation that although high speeds may not have been attained by 25 August 1987, the relatively new crevassing was then fairly extensive.

\section{Affected parts of the glacier}

Beginning 29 January 1988, observation flights over the glacier were made at about 2 week intervals, and oblique photographs were obtained. A reasonably well-defined surge front was identified in the photographs. Its progression is shown in Figure 2. Most of the glacier was activated by the surge. The upper and lower limits are also shown in Figure 2. Our estimation of the upper limit of the surge, which is not distinct, is based on crevasse patterns and is subject to some uncertainty, particularly in the eastern of the two upper basins. The lower limit of the surge was in debris-covered ice, apparently deposited by earlier surges. The surface of the lower part of the glacier was severely crevassed during the surge (Fig. 5). Tributary A (Fig. 2) participated strongly in the surge. On this tributary, as on the main trunk, the upper limit of the surge was not distinct but an estimate is given in Figure 2. During the surge, when the ice from tributary A and the main trunk were both active, the two streams were separated by an impressive narrow "septum" of high ice pinnacles. Tributary B also participated in the surge, although less strongly, as indicated by the post-surge moraine patterns where it merges with the main trunk. Interpretation of the behavior of tributary B in terms of crevasse patterns is 


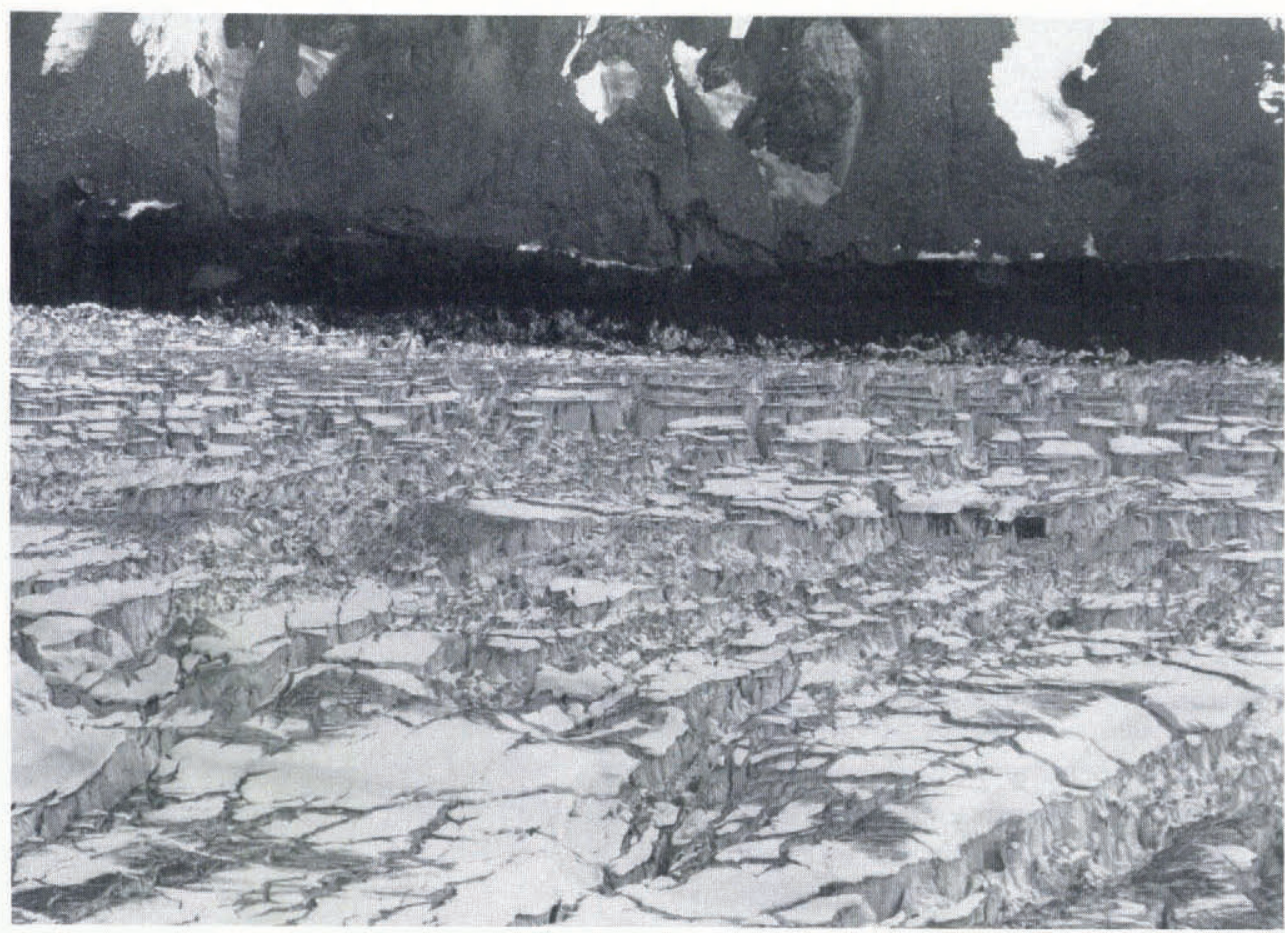

Fig. 5. Ice surface near $13 \mathrm{~km}$ in May 1988.

complicated by the severely crevassed icefall over which it passes just before it enters the main trunk (Fig. 2). Glacier $\mathrm{C}$ did not participate in the surge.

\section{Total displacement during the surge}

The total displacement of the glacier during the surge was measured at several points by comparing the positions of surface features (mostly potholes fairly close to the center line), which could be identified in vertical photographs taken before and after the surge. For pre-surge positions, we used NASA U2 photographs taken on 5 August 1980 (line 84, \#8583-8585) and 29 August 1981 (line 85, \#5409-5411). For post-surge positions, we used a mosaic of vertical $35 \mathrm{~mm}$ photographs which we took on 28 September 1989 and a Landsat TM image which was acquired on 18 September 1988.

Since we do not have vertical photography immediately before the surge, the estimates of the displacement during the surge itself depend somewhat upon assumptions about the motion from 1981-82 (the dates of the U2 photographs) and surge initiation in 1987. In Figure 6, the measured motion between the time of the U2 photographs and the termination of the surge is shown, together with the displacement during the surge itself under two different assumptions: (1) the pre-surge speed from 1981-82 to 1987 was constant at its measured 198183 average, and (2) the pre-surge speed continued the $20 \%$ annual increase which was observed from 1981-82 to $1982-83$, as described above. Since the adjustments to the measured motion were based on pre-surge speed measurements that were made at only one of the points, the speed at the other points had to be estimated. However, the adjustments at these other points were relatively small and the resulting contribution to the uncertainty in the displacement during the surge is probably not significant.
We expect that the most realistic estimate of total surge motion is the one resulting from the assumption of pre-surge $20 \%$ annual speed increase; the points representing this situation in Figure 6 have been connected with a curve. This interpretation is consistent with the motion of a set of potholes (one of the markers used to obtain the data in Figure 6 at about $25 \mathrm{~km}$ ) between 1981-82 (when the NASA U2 photographs were taken) and 25 August 1987. The position of these potholes at the latter date was estimated to an uncertainty of about $200 \mathrm{~m}$ from one of the U.S. Geological Survey photographs (\#87R3-199). The position of the maximum in the displacement curve (at about $16 \mathrm{~km}$ ) is approximately the

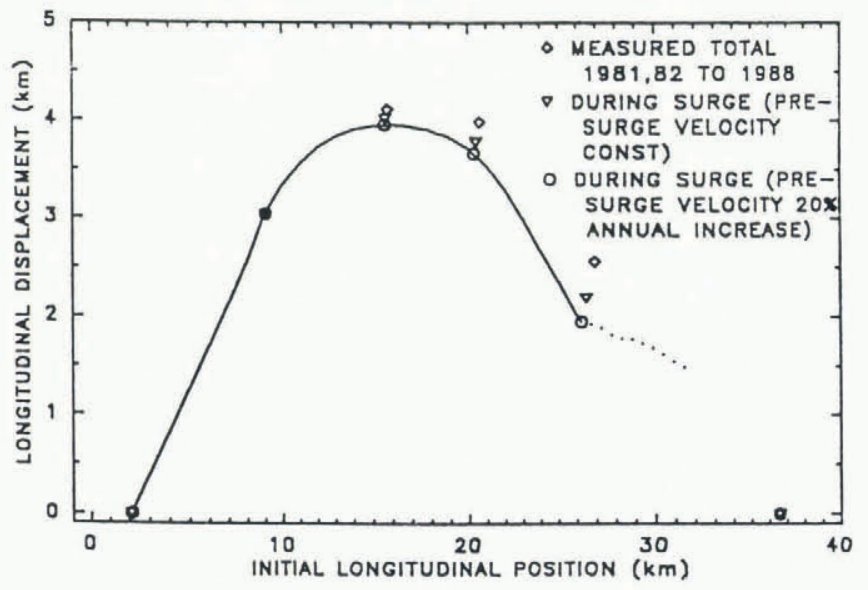

Fig. 6. Longitudinal displacement of the ice near the center line during the surge as a function of initial longitudinal position. The result requires estimation of the motion from 1981-82 to 1987, as explained in the text. The curve represents the best estimate of the result. Above $26.3 \mathrm{~km}$, the displacement has been estimated from continuity and measurements of elevation change made at the margin of the glacier. 
boundary between the ice-"reservoir" area and the ice"receiving" area of the surge, as defined by Meier and Post (1969). This boundary is shown in Figure 2 and is seen to be well down in the ablation area of the glacier. The maximum displacement was about $4 \mathrm{~km}$. For the sake of comparison, the maximum width of the glacier is about the same.

\section{Irregular motion}

On 10 February 1988, two people made their way through the sheared margin on the northwest side of the glacier, and then to the center of the glacier at a longitudinal position of about $13 \mathrm{~km}$. The sheared margin consisted of ice rubble, with large blocks of ice (up to $7 \mathrm{~m}$ in length), separated by smaller "ice ball-bearings" $1 \mathrm{~m}$ or less in diameter, and, of course, crevasses. In this region, they could feel what appeared to be sudden acceleration events, which occurred at fairly predictable $1 \mathrm{~min}$ or so intervals. The events were accompanied by shattering of some of the "ice ball-bearings" and shifting of the larger blocks. Relatively quiescent conditions between events gave rise to the feeling that the sheared margin of the glacier was moving in a jerky fashion.

\section{GEOMETRY AND SHEAR STRESS}

\section{Surface elevation}

A longitudinal profile of elevation along the center line was obtained from U.S. Geological Survey topographic maps, which have $100 \mathrm{ft}$ [30.5 m] contour intervals and are based on 1949 photography. This profile is shown in Figure 7a. During the summer of 1982, several surfaceelevation measurements were made at the three points shown in Figure 2 using the altimeter of a helicopter, or, in the case of the highest point, by surveying relative to fixed bedrock points. Elevations were referenced to the U.S. Geological Survey bench mark "Sitna" (Fig. 2). The positions of the lower two points were estimated from the glacier surface by compass bearings to known points. The estimated elevation uncertainty is about $18 \mathrm{~m}$. These data were used to estimate the 1987, pre-surge elevation, of the three points measured in 1982 . This was done by inferring a rate of elevation change obtained by comparison of the 1949 and 1982 elevations, and making a small extrapolation from 1982 to 1987 . The 1982 points are shown in Figure 7a.

The elevation of the surface was also determined on 18 May 1990, 22 months after the termination of the surge, again using a helicopter altimeter. The measurement points are shown in Figure 2. Compass bearings to known points were used to determine their position. Altimetry was also used to measure the ice-thickness change during the surge at points $\alpha$ and $\beta$ at the margin of the glacier; these points have longitudinal coordinates 28.5 and $31.2 \mathrm{~km}$ (Fig. 2). This was possible because ice from the pre-surge (1987) surface was left hanging on the valley walls at these points. The results are shown in Figure 7a. A continuous interpolation of the data is given by the indicated curve; it contains slightly more information than a smooth curve through the data because it includes

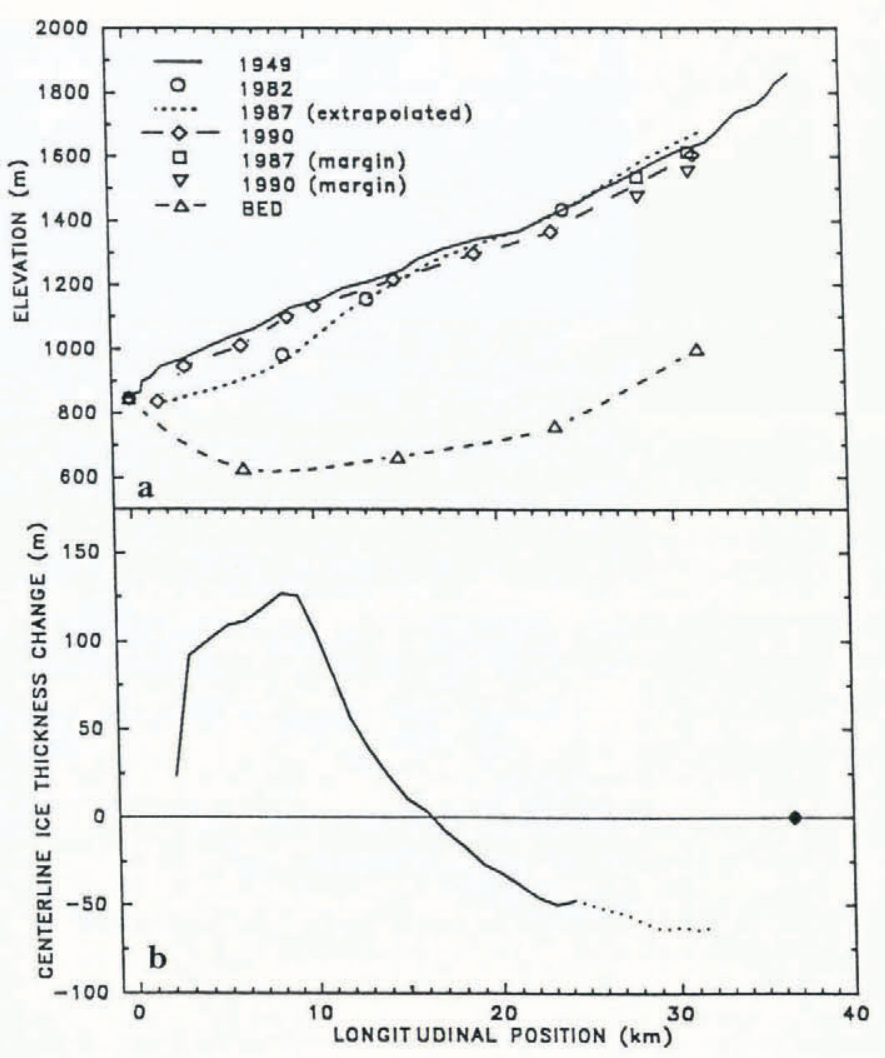

Fig. 7.a. Surface and bed elevations. The measurements were made near the center line, except for those noted by "margin" (see Fig. 2). The 1987 curve was estimated as described in the text. $b$. Ice-thickness change near the center line during the surge, as estimated from the data in Figure 7a. The dot near $37 \mathrm{~km}$ represents our estimate of the upper limit of the surge in the western of the two upper basins. Elevation changes measured at the side of the glacier have been used above $24.2 \mathrm{~km}$.

features of the surface profile noted in the field, and is influenced somewhat by the well-determined 1949 profile.

An interpolation of the 1987 profile is also given in Figure 7a. It is more subjective than the 1990 interpolated profile, because there are much less data. Above point $\mathrm{X}$ at $24.2 \mathrm{~km}$, it is assumed that the center-line elevation changes were the same as measured at the two points at the margins. This enables the 1987 elevations to be constructed from the 1990 elevations, but with relatively large uncertainty.

The ice-thickness change during the surge was found by subtracting the 1987 and 1990 profiles. This is shown in Figure $7 \mathrm{~b}$, in which the most uncertain part (above point $\mathrm{X}$ ) is dotted. A point of zero change, based on our estimate of the poorly defined upper limit of the surge in the western upper basin, is also shown. The reservoir and receiving areas are defined by the areas of thinning and thickening, respectively. The boundary between them is at about $16 \mathrm{~km}$.

Although these data give a reasonable picture of preand post-surge topography, they contain no information about its possibly complex evolution during the surge, when there may have been initial thickening followed by thinning associated with propagation of the surge front. Photographs taken at the lower of two time-lapse camera sites (Fig. 2) were inspected with this in mind. They suggest that there, from about 12 March 1988, and 
possibly from the beginning of the photography a month earlier, the surface elevation dropped monotonically until surge termination. This is not surprising because the surge front was far down-glacier from this site over this interval (Fig. 2).

\section{Ice thickness}

The ice thickness was measured on 18 May 1990 at several points using monopulse radar. The results of measurements made near the center line are shown in Figure 7a. Several measurements were also made across one transverse section at $23.4 \mathrm{~km}$.

\section{Width}

The width of the glacier was measured from our photographs, maps and Landsat imagery. The width changed little during the surge, except near the lower limit of the surge, where the width of the activated ice was used in the mass-continuity calculations described below.

\section{Shear stress}

The basal shear stress in 1949, 1987 and 1990 was calculated by the methods of Kamb and Echelmeyer (1986) from the measured surface- and bed-elevation profiles and a stress shape factor of 0.63 , the latter estimated by the methods of Nye (1965) from the shape of the cross-section measured at $23.4 \mathrm{~km}$. A triangular averaging window with a base of $4 \mathrm{~km}$ (about six times the ice thickness) was used; the validity of this averaging depends upon the density of the data, which is highest for 1949. The result is shown in Figure 8.

The pre-surge stress, represented by the 1987 curve in Figure 8 , shows a broad, secondary maximum in the vicinity of the boundary between the reservoir and receiving areas, and reaches a maximum of $1.3 \times$ $10^{5} \mathrm{~Pa}$ at roughly $28 \mathrm{~km}$. It should be recalled that there is considerable uncertainty in the 1987 surface geometry, and therefore in the shear stress, especially above point $\mathrm{X}$ at $24.2 \mathrm{~km}$. The data are more reliable for the other years, particularly 1949, but in all cases there is considerable uncertainty in the stress shape factor and in the details of the bed geometry. Also, complications due to the entry of

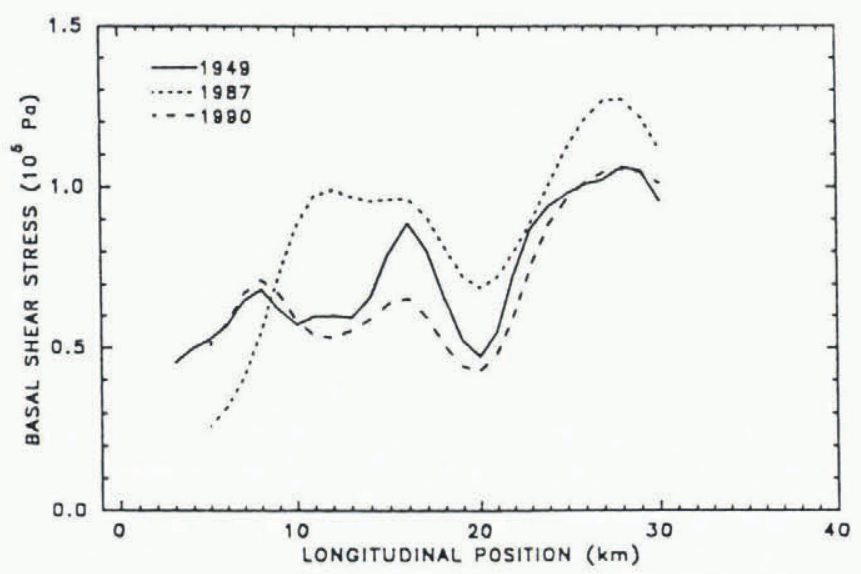

Fig. 8. Estimated shear stress at the base of the glacier at three times. tributaries A and B (Fig. 2) are neglected. High on the glacier, above $32 \mathrm{~km}$, there are no data and the geometry is complicated by the existence of two more-or-less distinct upper basins as seen in Figure 2. Neither the pre- nor post-surge stress regimes of the glacier appear to be particularly unusual.

\section{MASS CONTINUITY, ICE-FLOW REGIME AND ICE FLUX}

\section{Mass continuity applied to the changes in geo- metry}

Mass continuity provides a connection between the displacement of the ice (Fig. 6) and the ice-thickness change (Fig. 7b) during the surge. It can be used to give information about the flow regime of the ice during the surge, the volume of ice which was transported, and the displacement of the ice above the highest point that was directly measured. We characterize the flow regime by a volume-transport shape factor $g$ defined by

$$
Q(x)=g(x) A(x) D(x)
$$

in which $Q$ is the total volume of ice transported during the surge in the main trunk of the glacier through a transverse cross-section located at a longitudinal position $x, A$ is the area of the transverse cross-section and $D$ is the displacement of the ice at the center line during the surge. For plug flow, $g$ should be unity, while for nonsurge, non-slip flow in a channel like that of West Fork Glacier, $g$ should be typically about 0.6 , using the results of Nye (1965).

The details of the calculation of the shape factor, the volume of the ice transported and the displacement on the upper part of the glacier are described in the Appendix. The results are as follows.

\section{Shape factor}

The volume-transport shape factor $g$ shows a marked change at about $10 \mathrm{~km}$ (Fig. 9). Below $10 \mathrm{~km}$ its average

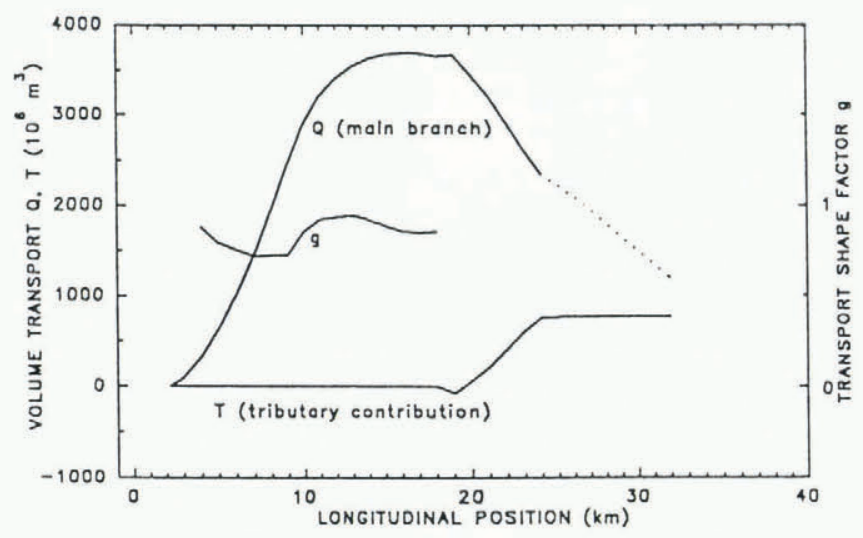

Fig. 9. Volume of ice transported during the surge in the main trunk of the glacier (Q), the contribution of the tributaries (T) (expressed as the integrated volume decrease of the tributaries below position $x$ on the main trunk) and volume transport shape factor $(\mathrm{g})$. Above $24.2 \mathrm{~km}$ the estimation of $Q$ is less direct, as explained in the Appendix. 
value is 0.78 ; from 10 to $18 \mathrm{~km}$ it is 0.90 . It is quite possible that the difference is due to the presence of the bend near $10 \mathrm{~km}$, which distorts the surge front (Fig. 2) and probably the transverse profile of speed, and therefore the flow regime as characterized by $g$. Uncertainty in the channel shape might also contribute to the difference. The value 0.90 above $10 \mathrm{~km}$ is closer to plug flow and probably more typical of surge motion; a value close to unity also seems consistent with the data.

\section{Volume of ice transported}

The volume of ice transported in the main trunk during the surge $Q(x)$, and the contribution of the tributaries $T(x)$, are shown in Figure 9. $T(x)$ represents the integrated volume decrease of the tributaries below position $x$ on the main trunk of the glacier. The total contribution of the tributaries is roughly $750 \times 10^{6} \mathrm{~m}^{3}$, about $20 \%$ of the maximum volume transported in the main trunk. This maximum occurs at about $16 \mathrm{~km}$, the position of the boundary between reservoir and receiving areas as estimated from the thickness change.

\section{Displacement}

The displacement of the ice $D$ above its highest measured point at $x=26.3 \mathrm{~km}$ is shown in Figure 6. The break in slope in $D$ (which is not necessarily sharp nor precisely located at the point of highest measurement as sketched in Figure 6 ) is probably due to the entry of the ice from tributary A.

\section{Ice flux before and during the surge}

From the mass-balance measurements discussed in section II, T. S. Clarke (1991) estimated the balance flux at point $\mathrm{X}$ in Figure 2 to be $(109 \pm 30) \times 10^{6} \mathrm{~m}^{3}$ of ice per year. (This is the volume of ice accumulated annually above point $\mathrm{X}$, and is the same as the volume of ice that would flow annually through a transverse section at point $X$ if the glacier were in equilibrium.) He compared this with the actual annual ice flux at point $\mathrm{X}$ as estimated from the average center-line speed from July 1981 to June 1983, and concluded that the actual flux was about $0.44 \pm 0.18$ of the balance flux then. As discussed above, a $20 \%$ annual increase in speed was observed between 1981 and 1983. If it persisted during the 5 years before the surge, then at surge initiation the annual flux was $(0.44 \pm 0.18) \times 1.2^{5}=1.09 \pm 0.45$ of the balance flux. Therefore, although the uncertainties are large, we must take seriously the possibility that the glacier was already transporting balance flux (or even more) at point $\mathrm{X}$ by the time the rapid surge motion began. This calls into question what at first seems an intuitively reasonable assumption, that surge-type glaciers transport significantly less than balance flux at all points throughout the quiescent phase.

The volume of ice transported past point $\mathrm{X}$ during the surge was estimated from Figure 9. It is equivalent to about 21 years of balance flux. If similar surges occur with a period of about 52 years and if the balance can be considered relatively constant, this means that about $21 / 52=0.4$ of the total ice transport past point $\mathrm{X}$ occurs during surges. Farther down-glacier, at the boundary between the receiving and reservoir areas for example, it is likely that the fraction of ice transport which occurs during surges is larger.

\section{SPEED DURING AND AFTER THE SURGE}

\section{Speed during the surge - measurement}

Speed during the surge was measured by time-lapse photography at two points. For several reasons, including the necessity of using many different natural surface features as targets, the rotational instability of one of the cameras, and a paucity of survey data, the reduction of the data was a major task and has been described separately (Harrison and others, 1992). The methods used were an extension of those described by Harrison and others (1986b,c). The cameras were located at the sites labeled Lower and Upper in Figure 2. The approximate locations of the targets are also shown; they were not on the center line. Data were acquired from 12 February 1988 to 3 August 1989 at the lower site, and from 6 April 1988 to 4 November 1988 at the upper. The results are given in Figure 10. At Upper Camera, the scale of the speed was not determined directly, but was taken to be the same as at Lower Camera multiplied by
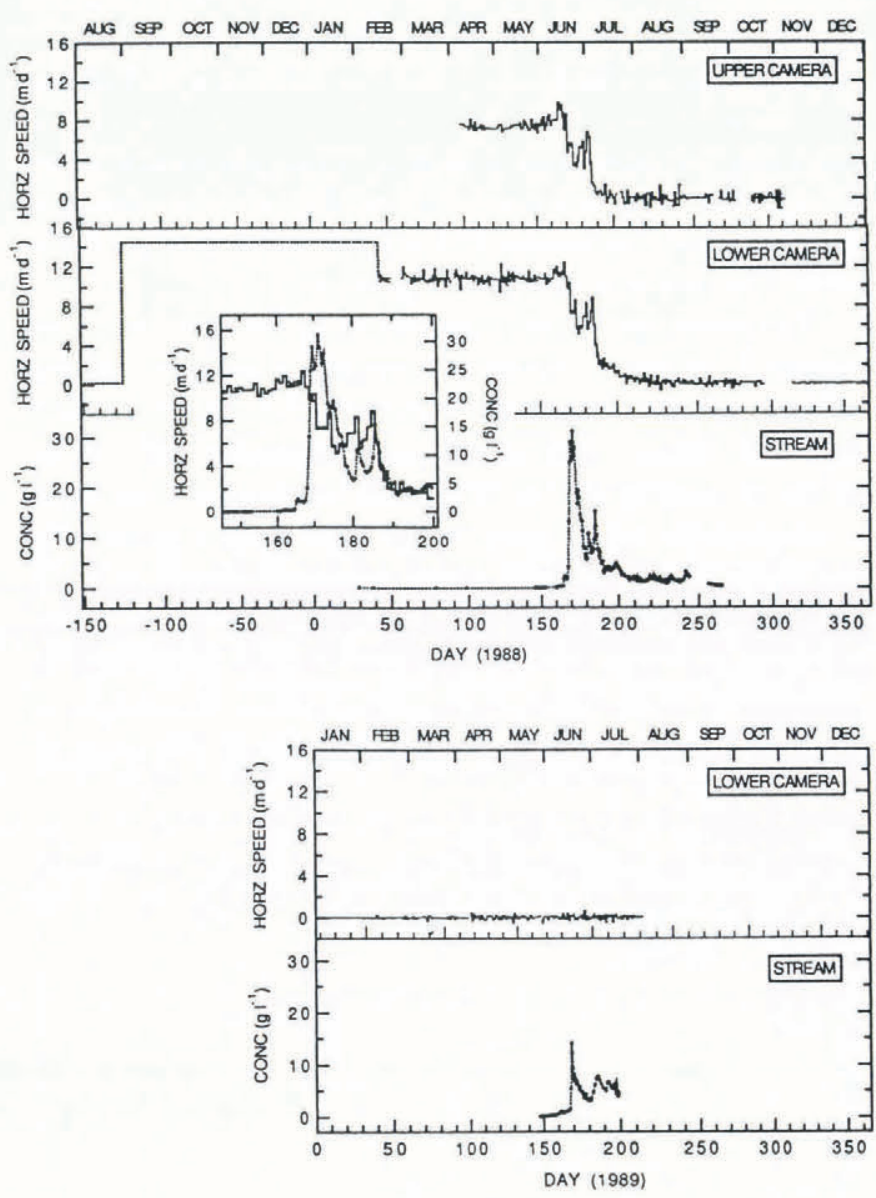

Fig. 10. Speed at the two camera sites and sediment concentration at the stream-sampling site shown in Figure 2. In the insert, between panels 2 and 3, the time-scale is expanded and the speed and concentration curves are superimposed. The dashed line in panel 2 shows one possible scenario for the speed before the cameras were installed, as explained in the text. 
the ratio of the displacements of the ice at the two sites during the surge.

At Lower Camera, the displacement during the complete surge (Fig. 6) and the displacement during the period of camera measurements (beginning on 12 February 1988) are both known, the latter by integration of the measured speed. The displacement between the onset of the surge and the beginning of the measurements follows by subtraction. This places a constraint between the timing of surge initiation and the average speed during this interval. The simplest scenario, in which an abrupt onset of rapid motion is taken to be 25 August 1987, the date of the photograph of Figure 3, is illustrated by the broken line in the second panel of Figure 10. This speed is seen to be slightly greater than that measured later but, when the uncertainties in the scale of the measured speed (roughly 10\%) and in the displacement are taken into account, the difference may not be significant. In this scenario, then, the speed was essentially constant during the surge until shortly before its termination. However, since large displacements probably did not occur before the photograph of 25 August 1987 (or else the margins of the glacier would have been more sheared, as noted above) and high speed may well have started later, the average surge speed over some interval before 12 February 1988 could have been significantly larger than that measured after 12 February.

The speed at Lower Camera was almost constant (within the systematic errors caused by uncertainty in camera-pointing direction, as discussed by Harrison and others (1992)), from 12 February 1988 to the first part of June, when a complex termination phase lasting about a month began. We define this phase to have begun with the slight increase in speed, more noticeable at Upper Camera, which peaked in mid-June. Several large acceleration and deceleration events occurred soon after, the only such events during the observation period. The end of the surge, well-defined to within a day or so, was 6 July 1988. A slow decay in the already low speed occurred subsequently, as discussed below. A striking result is that the structure of the rapid speed variations at both sites, which are about $9 \mathrm{~km}$ apart, was virtually identical during the termination phase, at least within the $1 \mathrm{~d}$ time resolution of the data.

\section{Speed during the surge - advancing surge front}

During the interval 29 January 29-18 March 1988, a reasonably well-defined surge front advanced from 7.6 to $3.8 \mathrm{~km}$ (Fig. 2), an average rate of $78 \mathrm{~m} \mathrm{~d}^{-1}$. Simple continuity considerations (Raymond and others, 1987), neglecting changes in the shape of the front, indicate that the speed of the ice $u$ just upstream of the front and the speed of the front itself $u_{\text {front }}$ should be related by

$$
u=\frac{\delta H}{H} u_{\text {front }}
$$

in which $\delta H$ is the unknown height of the front and $H$ is the ice thickness just upstream of the front. If the thickening of the receiving area took place entirely by propagation of the front, $\delta H$ would be equal to the thickness change for the entire surge plotted in Figure $7 \mathrm{~b}$ and $H$ would be close to the 1990 ice thickness obtained from Figure 7a. Making these approximations, Equation (2) implies a speed of about $23 \mathrm{~m} \mathrm{~d}^{-1}$ for the ice just upstream of the front over this 29 January-18 March interval. This should be considered only an upper limit because of the approximations. It is also worth noting that the speed may be quite peaked upstream of such a front (Raymond, 1987). At any rate, this speed is about twice that measured higher on the glacier, at Lower Camera (Fig. 10).

During the interval $18 \mathrm{March}-23$ June 1988, the front advanced from 3.8 to $1.8 \mathrm{~km}$ (Fig. 2), an average rate of $21 \mathrm{~m} \mathrm{~d}^{-1}$. The corresponding speed of the ice is about $12 \mathrm{~m} \mathrm{~d}^{-1}$, which is only half that of the upper limit obtained for the previous interval. This suggests a significant decrease in speed near the surge front during the latter part of the surge, but not conclusively because of the approximations made in the evaluation of $\delta H$ and $H$.

\section{Speed after the surge}

As noted above, we may define the final surge termination at both measurement sites as occurring within a day of 6 July 1988. However, at least at Lower Camera, there is a slow decay of speed which is detectable over most of the 1 year data-acquisition period after the surge. The first part of the decay can be seen in Figure 10. The latter part can be seen by averaging the data over sufficiently long time intervals to overcome the effect of noise (Fig. 11). It

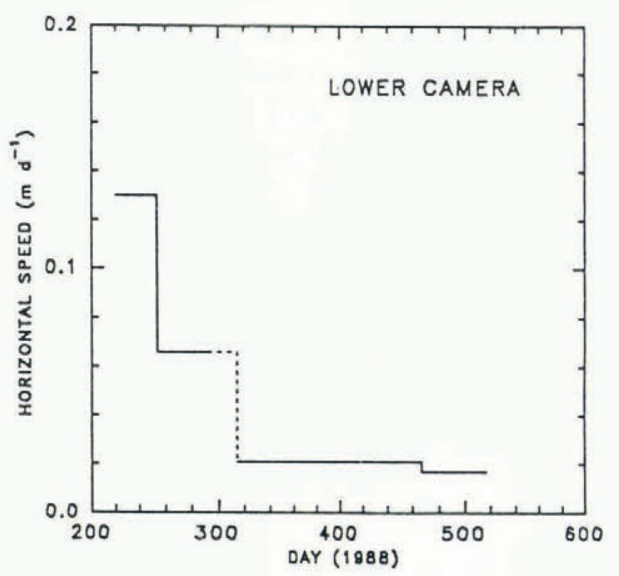

Fig. 11. Post-surge behavior of the speed at the lower camera site.

is seen that the post-surge speed eventually decreases to a very small value, close to $0.020 \mathrm{~m} \mathrm{~d}^{-1}$, with a decay halflife of several months. This is the same as the predicted speed under conditions of no basal sliding using the simplest methods, with Paterson's (1981) suggested values for the parameters describing the flow of temperate ice, a stress shape factor of 0.63 and values of thickness and shear stress at $13 \mathrm{~km}$ taken from Figures $7 \mathrm{a}$ and 8 , respectively.

\section{CHARACTERISTICS OF THE DISCHARGE STREAM}

Suspended-sediment concentration, turbidity, electrical conductivity and stage were measured in the stream draining the glacier, at the site near the terminus shown 
in Figure 2. (No sediment was found in another, much smaller stream, farther to the east.) Limited measurements were also made at several points as far as $250 \mathrm{~km}$ downstream on Susitna River. Most of these results will be discussed separately. Here, we focus on the results of the suspended-sediment measurements near the terminus.

During winter and spring 1988, water samples were taken during irregular visits to the stream. From early June 1988, an automatic water sampler (ISCO Model 2700) was used to obtain samples twice daily, which were later analyzed for sediment concentration. The results are shown in Figure 10. During the 1988 winter and spring sampling period, the samples showed no trace of turbidity, even though the surge was in full swing. We conclude that no basal water was escaping from the glacier then. The first sediment, along with an increase in stage, appeared in early June, about the time of the onset of the termination phase of the surge (defined above as the time of the slight increase in speed which immediately preceded the first deceleration event). The sedimentconcentration maxima have a convincing correlation with deceleration events. The same is true of the stream stage. The highest stage of the year coincided with final termination. The concentration-speed correlation is best seen in the inset in panels 2 and 3 of Figure 10. The maximum sediment concentration of about $30 \mathrm{~g} \mathrm{l}^{-1}$ occurred near the beginning of the surge-termination phase. This is much higher than has been found in the drainage streams of non-surging glaciers in the central Alaska Range (e.g. Gaddis, 1974), and it is one or two orders of magnitude higher than we measured, at about the same time, in Susitna River above the confluence of the stream draining West Fork Glacier (Fig. 1).

The water sampler was also operated during the late spring and summer of 1989, a year after the surge (Fig. 10). There was no rejuvenation of the surge motion in 1989, but the timing of the onset of high sediment concentration and of the seasonal maximum were virtually the same as they had been in 1988 during the termination phase of the surge. This timing of sediment appearance is also typical for non-surging glaciers in this area. An interesting conclusion is that the seasonal cycle seems to be controlling the timing of sediment concentration under both surge and non-surge conditions. The sediment concentration in 1989 was lower than in 1988 but still high by normal standards. A flood, probably from the draining of the lake in front of glacier C, damaged the sampling site on 28 July 1989 and carried away the samples from the ten previous days. It had no detectable effect on the speed as measured at the lower camera site. A rather similar pattern of sediment concentration, but again less than the previous year, was also observed in 1990.

The lake in front of glacier C in Figure 2 apparently owes its existence to the surge. A U2 photograph (29 August 1981; line 85, \#5410) indicates that it did not exist in 1981. Photographs and observations show that by 23 June 1988 the lake had formed and was filling. There was little calving into it from glacier $\mathrm{C}$ then but by 19 July 1988 calving was active, the lake was full of icebergs and it had at least doubled in volume. The large size of the lake on 19 July suggests that it did not drain during surge termination on 6 July. Substantial floods, probably from the draining of the lake, occurred at the terminus in 1989 (peaking on $28 \mathrm{July}$, as noted above) and probably again in 1990 (peaking on 26 July).

\section{COMPARISON WITH OTHER SURGES}

The difficulty of defining a surge-type glacier was first discussed in detail by Meier and Post (1969). While there is agreement that surges are quasi-periodically occurring episodes of relatively rapid motion, surges are often quite different from glacier to glacier, or even for a single glacier. It has therefore been of considerable interest to determine the systematics of surge-type glaciers by comparing them both with other surge-type glaciers and with "normal" glaciers (e.g. Post, 1960; Meier and Post, 1969; G. K. C. Clarke and others, 1986; Echelmeyer and others, 1987; Raymond, 1987; Wilbur, 1988; Dowdeswell and others, 1991; G. K. C. Clarke, 1991). These discussions are continued here, with emphasis on West Fork Glacier and its comparison with Variegated Glacier, the most-studied surging glacier to date, and the one most familiar to us (Kamb and others, 1985; Raymond and Harrison, 1988). A comparison of the Variegated Glacier surge with those of other glaciers has been given by Raymond (1987).

\section{Size and setting}

The most obvious difference between West Fork Glacier and Variegated Glacier is size; length $40 \mathrm{vs} 20 \mathrm{~km}$, typical thickness 600 vs $350 \mathrm{~m}$ and average surface slope of the surging length $1.5^{\circ}$ vs $5.4^{\circ}$ for West Fork Glacier and Variegated Glacier, respectively. West Fork Glacier receives moderate precipitation, whereas Variegated Glacier's precipitation is heavy. Both almost certainly have temperate beds. The surge recurrence period for West Fork Glacier (slightly over 50 years) is roughly three times that of Variegated Glacier.

Both glaciers lie in a complex geologic environment and flow along, or are cut by major faults (see Frost, 1976). This suggests that the beds of both glaciers are complex, in the sense that easily erodible materials could lead to deformable basal sediments and complex subglacier drainage systems. It has been noted (Post, 1969) that in the Alaska Range many surging glaciers (in addition to West Fork Glacier) are found within the prominent Denali Fault System, although other mountain regions with major and active faults do not necessarily have surging glaciers. On the other hand, Post noted that there are no surging glaciers in the granitic - and we may speculate, generally more competent-rocks of the Coast Mountains. It appears that a complex bed (as defined above) cannot be eliminated as a necessary (though not sufficient) condition for surging.

\section{Pre-surge behavior}

The pre-surge data are limited from West Fork Glacier, but the $20 \%$ annual increase in annual speed noted several years before the surge is similar to the progressive acceleration which occurred on Variegated Glacier (Raymond and Harrison, 1988) prior to the rapid surge 
motion. A similar pattern, although more complex than observed on Variegated Glacier, was observed on Medvezhiy Glacier (Dolgushin and Osipova, 1975, 1978). Some glaciers may be more complicated still; Post (unpublished) believes that precursor false starts to surges, which may fade as rapidly as they start, are common. At any rate, significant changes in the flow regimes of many surge-type glaciers evidently occur several years before the rapid surge motion. If, as discussed above, West Fork Glacier was transporting balance flux at point $\mathrm{X}$ by the time of surge initiation, it suggests that during the pre-surge acceleration phase events were already in progress which made a surge almost inevitable regardless of possible changes in balance. The significant pre-surge acceleration of West Fork and Variegated Glaciers would have permitted prediction of the imminence of their surges several years in advance. In contrast, the speed of Black Rapids Glacier (like West Fork Glacier, a large surge-type glacier in the central Alaska Range; Fig. 1) has undergone a large oscillation with a period of roughly 15 years (Heinrichs and others, 1991), but no surge has occurred yet.

\section{Seasonal timing}

The most obvious difference in seasonal timing between West Fork and Variegated Glaciers is that the surge of the latter took place in two phases, the first beginning (probably suddenly) in early January 1982, and the second (relatively smoothly) in October 1983. Both phases terminated abruptly in late June or early July, as did the single phase of the West Fork Glacier surge. The initiation of the West Fork Glacier surge was probably some time soon after 25 August, as discussed above. Raymond (1987), reviewing the limited evidence available, noted that there were no known exceptions to surge initiation in winter; this was supported subsequently by observations of Peters Glacier which surged in 1986-87 (Echelmeyer and others, 1987). We therefore need to consider whether the timing of the West Fork Glacier surge fits into this picture.

The timing of surge initiation is critical for testing an idea about surge initiation discussed by Raymond (1987). The basic idea is that, as the water supply from the surface turns off late in the season, the pressure in the main internal water passageways draining the glacier rises as they shrink in response to decreased melting at their walls (Röthlisberger, 1972). If the pressure rises sufficiently, water stored within the glacier might not be able to reach the passageways but might be diverted to form a distributed drainage system at the glacier bed at the expense of the passageways, which could collapse. (The "linked cavity" system of Kamb (1987) is one of the possible configurations of such a distributed system.) If this were to occur, it would have to do so before most of the stored water had been discharged, and the discharge rate had decreased to its base winter value. The collapse of the original drainage system could initiate the surge.

The behavior of West Fork Glacier seems to be consistent with this idea, even though the surge could have begun as early as the latter part of August. In this part of the Alaska Range, late August is usually a time of little or no surface melt, except low on the glaciers, and it is likely that the glaciers' internal drainage systems are already contracting by this time. Indeed, we have observed that late-summer rainstorms often cause shortlived motion events on the nearby Black Rapids and Fels Glaciers (Fig. 1), probably because of the transient high water pressures which they induce in the already contracted passageways. The early initiation of the West Fork Glacier surge relative to that of Variegated Glacier could therefore be interpreted as a relatively rapid collapse of the drainage system in response to the turning off of the surface water, and not due to a different kind of triggering mechanism. Also, the greater thickness of West Fork Glacier may be a factor in the more rapid collapse. Raymond's (1987) hypothesis of winter-surge initiation may therefore hold if "winter" is defined as the time that surface water is absent. This important question still seems to be open. Post (unpublished) believes that, although rapid acceleration seems to occur during winter months, shearing along the margins of some surging glaciers may begin when run-off is still high.

The timing of surge termination does not seem to be as uniform as initiation, as discussed by Raymond (1987) and Echelmeyer and others (1987). It is probably common for surges to terminate suddenly early in the melt season when surface water first becomes abundant, as did West Fork Glacier and both phases of the Variegated Glacier surges. However, some surges, such as that of Peters Glacier (Echelmeyer and others, 1987), terminate in winter, which shows that the input of surface water is not essential to termination. The position of the surge front must be a significant variable. When it is in the terminal region, termination may occur at any season. If it has not reached this region by the time that surface water becomes abundant, termination may occur followed by re-initiation when the surface water next turns off - the pattern followed by Variegated Glacier.

\section{Surge speed and changes in geometry}

The West Fork Glacier surge was a moderate surge of a large glacier (see Meier and Post, 1969). The changes in surface elevation (roughly $60 \mathrm{~m}$ draw-down in the reservoir area and up to $120 \mathrm{~m}$ thickening in the receiving area) were somewhat greater than observed on Variegated Glacier, but the surface of West Fork Glacier was less crevassed. The maximum estimated pre-surge basal shear stress was higher on Variegated Glacier $\left(1.8 \times 10^{5} \mathrm{~Pa}\right)$ than on West Fork Glacier $(1.3 \times$ $\left.10^{5} \mathrm{~Pa}\right)$. The measured speed of West Fork Glacier was comparable to that measured on upper Variegated Glacier during the second phase of its surge, but the $50 \mathrm{~m} \mathrm{~d}^{-1}$ or more reached briefly on lower Variegated Glacier was probably never approached during the West Fork Glacier surge. Both surges were followed by a further, slow decay of speed which lasted several months (see Harrison and others, 1986c).

The most obvious difference in the structure of the two surges was that Variegated Glacier's took place in two well-defined phases, as discussed above. In addition, a short-lived but major deceleration event took place during the second winter of the Variegated Glacier surge. In contrast, the surge speed of West Fork Glacier (at least where it is best known at Lower Camera) was 
essentially constant from the beginning of the observations midway through the surge, until the beginning of the surge-termination phase. It is also possible, as discussed above, that the average speed was not greatly different in the earlier phase of the surge, before the detailed observations of speed began.

Despite these differences, there are remarkable similarities in the behavior of the speed. The termination phases of the West Fork and Variegated Glaciers surges were complex but, in both cases, the behavior at widely separated points showed coherence. In the Variegated Glacier surge, events at different points were slightly phase-shifted by an amount corresponding to downglacier propagation at speeds of $0.6-0.7 \mathrm{~km} \mathrm{~h}^{-1}$. The time resolution of the speed measurements at the two camera sites on West Fork Glacier was marginal to identify a similar effect but some shift may have been present. Another similarity is that a premonitory acceleration heralded the beginning of the termination phase in both cases, although it was much stronger and lasted longer on Variegated Glacier. Also, in both surges, the deceleration events, including the final one, were abrupt.

\section{Water and sediment characteristics}

The most striking similarity in the surges of West Fork and Variegated Glaciers is the behavior of the streams draining the glaciers. In the case of West Fork Glacier, no sediment nor turbidity were visible in samples of the stream water until the beginning of the termination phase, after which deceleration events were accompanied by floods of sediment-charged water. The largest was the flood which accompanied the final termination. In the case of Variegated Glacier (Humphrey, 1987), the water was unusually turbid throughout the surge, but the pattern of coincidence between deceleration events and floods with extremely high sediment concentration was the same. Peak sediment concentrations were slightly lower on West Fork Glacier but still an order of magnitude or more greater than what might be considered normal. It is clear that no water at all was escaping from the base of West Fork Glacier until the beginning of the termination phase. The disruption of the basal drainage system was the central conclusion of the studies of the Variegated Glacier surge; this phenomenon was even more complete in the case of the West Fork Glacier surge, at least as it affected the stream. The studies on both of these glaciers confirm early suggestions (Röthlisberger, 1969; Post, unpublished) that surges are the result of the disruption of the internal drainage systems of glaciers. Although the information is less detailed, floods and high sediment discharge are known to have occurred in the surges of other glaciers; e.g. Black Rapids Glacier, Alaska (Hance, 1937), Peters Glacier, Alaska (Echelmeyer and others, 1987) and Bruarjökull, Iceland (Thorarinsson, 1969), and several in Central Asia (Shchegolva and Chizhov, 1981). This suggests that the disruption of the internal drainage system, which results in large water storage and high basal pressure, is the usual, if not necessarily universal, cause of glacier surges.

\section{SUMMARY AND CONCLUSIONS}

A surge of West Fork Glacier, a $40 \mathrm{~km}$ long, essentially temperate glacier situated in a complex geologic setting in the Alaska Range, began just after the end of the melt season 1987 and terminated suddenly 10 months later on 6 July 1988. The previous surge occurred about 1935. Measurements from 1981 to 1983 indicated, at a point slightly below the equilibrium line, a $20 \%$ increase in annual speed. About half the balance flux was then being transported at this point, but it is quite possible that balance flux was reached before the initiation of rapid motion. Most of the glacier, including its two tributaries, was affected by the surge. The maximum total displacement of the ice during the surge was $4 \mathrm{~km}$. The maximum thinning in the reservoir area was roughly $60 \mathrm{~m}$ and the maximum thickening in the receiving area was $120 \mathrm{~m}$. The highest basal shear stress before the surge was about $1.3 \times 10^{5} \mathrm{~Pa}$, which is not exceptionally high for a valley glacier.

Daily measurements of speed at Lower Camera (Fig. 2) indicated a speed of about $11 \mathrm{~m} \mathrm{~d}^{-1}$ from 12 February 1988 to early June 1988. The speed during the earlier part of the surge was at least as large. The termination phase of the surge, the onset of which was defined by a slight acceleration, began in early June, and was marked by events of rapid acceleration and deceleration until the final termination, which was abrupt. The speed varied coherently at two measurement sites about $9 \mathrm{~km}$ apart. No turbidity or sediment were found in the stream draining the glacier until the beginning of the termination phase. Sediment concentrations of $30 \mathrm{~g} \mathrm{l}^{-1}$ were reached during the first deceleration event and each such subsequent event was accompanied by a concentration maximum. After surge termination, the speed at Lower Camera showed an additional deceleration lasting several months. Higher-than-normal sediment concentration in the stream, with a similar seasonal timing of the first sediment appearance, also occurred in 1989 and 1990, but there was no resumption of surge speed-not surprisingly, since the surge front at the time of termination was not far from the positions of moraines deposited by previous surges.

Comparison of the surge of West Fork Glacier with that of the smaller Variegated Glacier indicates several differences, which may be summarized by noting that the West Fork Glacier surge was a considerably simpler event. However, these differences do not indicate differences in the basic mechanisms. The implications of that study and of more limited observations on several other glaciers are therefore confirmed. First, although the geometry and resulting stress fields may be important in setting the stage for surge initiation, surge initiation occurs after water supply from the surface turns off. Secondly, the rapid motion is caused by disruption of the internal drainage system. Moreover, the similar behavior of the speed during both surges, and the similar relationship of speed to water and sediment discharge, suggest that the details of the mechanism of fast motion were the same in both cases. Other similarities, such as characteristic pre- and post-surge behavior, the location of both glaciers in a complex geologic setting, and high erosion rates implied by the sediment discharges, can be identified.

Needless to say, the problem of glacier surging cannot now be considered solved. The most important unan- 
swered question is the structure of the bed, a rigid bed everywhere beneath the glacier being one extreme, and a deformable bed everywhere, the other. Aspects of this question have been discussed by several authors and have been summarized by Raymond (1987). The connection between bed structure and the nature of the internal drainage system is a parallel question (G. K. C. Clarke and others, 1984; Boulton and Hindmarsh, 1987; Fowler, 1987; Kamb, 1987, 1991). On the rigid bed, surging could be considered to have resulted from something akin to floating; on the deformable bed, it could have resulted from failure of the bed. These processes are quite different, even though they would both be caused by disruption of the internal drainage system. Nothing is known about the bed of West Fork Glacier, other than that it is situated in a highly faulted geologic environment. On Variegated Glacier, television observations, made at the bottom of several holes drilled with hot water in the reservoir area about 2 years before the surge, suggested that most of the basal motion (at least in the small area studied) was taking place in a basal debris layer (Harrison and others, 1986a). An actively deforming debris layer is known to be present beneath at least a part of Trapridge Glacier and Breidamerkurjökull (Thorarinsson, 1969; Boulton and Jones, 1979; G. K. C. Clarke and others, 1984), both surge-type glaciers. Evidently, the question of bed structure remains open. The observation of deforming sediments beneath parts of two other kinds of rapidly moving ice masses, Antarctic ice streams (Blankenship and others, 1987; Engelhardt and others, 1990) and tide-water glaciers (Engelhardt and others, 1987), should be kept in mind. However, the question is not only the structure of the beds of rapidly moving ice masses, but whether these beds are systematically different from the beds of "normal" glaciers, under which active sediment layers have also been found (e.g. Engelhardt and others, 1978; Brand and others, 1987).

\section{DATA AVAILABILITY}

All of the data shown in the figures of this paper are available in numerical form on a disk from the authors or from World Data Center A, Glaciology.

\section{ACKNOWLEDGEMENTS}

We acknowledge the important contributions of several people: R. Krimmel and A. Post for the use of their photographs which constrained the initiation of the surge, B. Weertman for his role in the radar observations, D. Cosgrove, T. S. Clarke, J. DeMallie, and M. Wumkes for their roles in data reduction and field operations, D. Hall for providing the Landsat image, and D. Johnson and others, whose efforts in the feasibility studies for the proposed Susitna hydro-electric project produced the presurge data. This paper has benefited greatly from the comments of T. S. Clarke, R. Krimmel, A. Post and an anonymous reviewer. Financial support was from U.S. National Science Foundation grants DPP-8519110, DPP8822624, DPP-8520527 and DPP-8822584.

\section{REFERENCES}

Blankenship, D. D., C. R. Bentley, S. T. Rooney and R. B. Alley. 1987. Till beneath Ice Stream B. I. Properties derived from seismic travel times. 7. Geophys. Res., 92(B9), 8903-8911.

Boulton G.S. and R.C.A. Hindmarsh. 1987. Sediment deformation beneath glaciers: rheology and geological consequences. F. Geophys. Res., 92(B9), 9059-9082.

Boulton, G.S. and A.S. Jones. 1979. Stability of temperate ice caps and ice sheets resting on beds of deformable sediment. f. Glaciol., 24(90), $29-43$.

Brand, G., V. Pohjola and R. LeB. Hooke. 1987. Evidence for a till layer beneath Storglaciären, Sweden, based on electrical resistivity measurements. F. Glaciol., 33(115), 311-314.

Brewer, W. M. and C. Craddock. 1989. Geologic map of the Mount Deborah area, Central Alaska Range, Alaska. Fairbanks, AK, Alaska Division of Geological and Geophysical Surveys. (Report of Investigations 89-1.)

Clarke, G. K. C. 1991. Length, width and slope influences on glacier surging. J. Glaciol., 37(126), 236-246.

Clarke, G. K. C., S. G. Collins and D.E. Thompson. 1984. Flow, thermal structure, and subglacial conditions of a surge-type glacier. Can. F. Earth Sci., 21(2), 232-240.

Clarke, G. K. C., J. P. Schmok, C. S. L. Ommanney and S. G. Collins. 1986. Characteristics of surge-type glaciers. J. Geophys. Res., 91(B7), 7165-7180.

Clarke, T.S. 1986. Glacier runoff, balance and dynamics in the upper Susitna River basin, Alaska. (M.S. thesis, University of Alaska.)

Clarke, T. S. 1991. Glacier dynamics in the Susitna River basin, Alaska, U.S.A. J. Glaciol., 37(125), 97-106.

Dolgushin, L. D. and G.B. Osipova. 1975. Glacier surges and the problem of their forecasting. International Association of Hydrological Sciences Publication 104 (General Assembly of Moscow 1971-Snow and Ice), 292-304.

Dolgushin, L.D. and G.B. Osipova. 1978. Balance of a surging glacier as the basis for forecasting its periodic advances. Mater. Glyatsiol. Issled. Khron. Obsuzhdeniya 32, 260-265.

Dowdeswell, J. A., G.S. Hamilton and J. O. Hagen. 1991. The duration of the active phase on surge-type glaciers: contrasts between Svalbard and other regions. f. Glaciol., 37(127), 388-400.

Echelmeyer, K., R. Butterfield and D. Cuillard. 1987. Some observations on a recent surge of Peters Glacier, Alaska, U.S.A. F. Glaciol., 33(115), 341-345.

Engelhardt, H. F., W. D. Harrison and B. Kamb. 1978. Basal sliding and conditions at the glacier bed as revealed by bore-hole photography. J. Glaciol., 20(84), 469-508.

Engelhardt, H., M. Fahnestock, N. Humphrey, B. Kamb and M. F. Meier. 1987. Rapid basal sliding in a large tidewater glacier caused by high basal water pressure. EOS, 68(44), 1272.

Engelhardt, H., N. Humphrey, B. Kamb, and M. Fahnestock. 1990. Physical conditions at the base of a fast moving Antarctic ice stream. Science, 248(4951), 57-59.

Fowler, A. C. 1987. A theory of glacier surges. 7. Geophys. Res., 92(B9), 9111-9120.

Frost, B. R. 1976. Reconnaissance geology along the Variegated Glacier, Saint Elias Mountains. Short Notes on Alaskan Geology. Geologic Report $51,1-4$.

Gaddis, B. L. 1974. Suspended-sediment transport relationships for four Alaskan glacier streams. (M.S. thesis, University of Alaska.)

Hance, J. H. 1937. The recent advance of Black Rapids Glacier, Alaska. J. Geol., 45(7), 775-783.

Harrison, W. D., L. R. Mayo and D. C. Trabant. 1975. Temperature measurements on Black Rapids Glacier, Alaska, 1973. In Weller, G. and S. A. Bowling, eds. Climate of the Arctic. Fairbanks, AK, University of Alaska. Geophysical Institute, 350-352.

Harrison, W. D., B. Kamb and H. Engelhardt. 1986a. Morphology and motion at the bed of a surge-type glacier. Eidg. Tech. Hochschule, Zürich. Versuchanst. Wasserbau, Hydrol. Glaziol. Mitt. 90, 55-56.

Harrison, W. D., C. F. Raymond and P. MacKeith. 1986b. Short period motion events on Variegated Glacier as observed by automatic photography and seismic methods. Ann. Glaciol., 8, 82-89.

Harrison, W. D., C.F. Raymond, C.S. Moore, E. Senear and P. MacKeith. 1986c. Time lapse camera data from Variegated and other glaciers 1979-1984. Fairbanks, AK, University of Alaska. Geophysical Institute. (Report UAG-R 304.)

Harrison, W.D., K.A. Echelmeyer, D. M. Cosgrove and C.F. Raymond. 1992. The determination of glacier speed by time-lapse photography under unfavorable conditions. J. Glaciol., 38(129), 257265. 
Heinrichs, T. A., L. R. Mayo, K. A. Echelmeyer and W. D. Harrison. 1991. Black Rapids Glacier, Alaska - unexpected behavior during the quiescent phase of a surge-type glacier. EOS, 72(44), Supplement, 158.

Humphrey, N. 1987. Basal hydrology of a surge-type glacier: observations and theory relating to Variegated Glacier. (Ph.D. thesis, University of Washington.)

Kamb, B. 1987. Glacier surge mechanism based on linked cavity configuration of the basal water conduit system. 7. Geophys. Res., 92(B9), 9083-9100.

Kamb, B. 1991. Rheological nonlinearity and flow instability in the deforming bed mechanism of ice stream motion. 7. Geophys. Res., 96(B10), 16,585-16,595.

Kamb, B. and K. A. Echelmeyer. 1986. Stress-gradient coupling in glacier flow: I. Longitudinal averaging of the influence of ice thickness and surface slope. 7. Glaciol., 32(111), 267-284.

$\mathrm{Kamb}$, W. B. and 7 others. 1985. Glacier surge mechanism: 1982-1983 surge of Variegated Glacier, Alaska. Science, 227(4686), 469-479.

Mayo, L. R. 1978. Identification of unstable glaciers intermediate between normal and surging glaciers. Mater. Glyatsiol. Issled. Khron. Obsuzhdeniya 33, 133-135.

Meier, M.F. and A. Post. 1969. What are glacier surges? Can. J. Earth Sci., 6(4), 807-817.

Nye, J. F. 1965. The flow of a glacier in a channel of rectangular, elliptic or parabolic cross-section. J. Glaciol., 5(41), 661-690.

Paterson, W. S. B. 1981. The physics of glaciers. Second edition. Oxford, etc. Pergamon Press.

Post, A.S. 1960. The exceptional advances of the Muldrow, Black Rapids, and Susitna glaciers. 7. Geophys. Res., 65(11), 3703-3712.

Post, A. 1969. Distribution of surging glaciers in western North America. 7. Glaciol., 8(53), 229-240.

Post, A. Unpublished. Water buoyancy: possible cause of high flow rates in surging glaciers. (Unpublished manuscript 1968.)

Raymond, C. F. 1987. How do glaciers surge? A review. J. Geophys. Res., 92(B9), 9121-9134.

Raymond, C. F. and W. D. Harrison. 1988. Evolution of Variegated Glacier, Alaska, U.S.A. prior to its surge. F. Glaciol., 34(117), 154 169.

Raymond, C.F., T. Jóhannesson, T. Pfeffer and M. Sharp. 1987. Propagation of a glacier surge into stagnant ice. J. Geophys. Res., 92(B9), 9037-9049.

Röthlisberger, H. 1969. Discussion of paper by Weertman. Can. J. Earth Sci., 6(4), 941-942.

Röthlisberger, H. 1972. Water pressure in intra- and subglacial channels. F. Glaciol., 11(62) 177-203.

Shcheglova, O.P. and O. P. Chizhov. 1981. Sediment transport from the glacier zone, Central Asia. Ann. Glaciol., 2, 103-108.

Sherwood, K. W., C. Craddock and T. E. Smith. 1976. Mineral occurrences in the Upper Wood River, Edgar Creek, and West Fork Glacier areas, Central Alaska Range. Fairbanks, AK, Alaska Division of Geological and Geophysical Surveys. (Special Report 14.)

Sturm, M. 1987. Observations on the distribution and characteristics of potholes on surging glaciers. J. Geophys. Res., 92(B9), 9015-9022.

Sturm, M. and D. M. Cosgrove. 1990. Correspondence. An unusual jökulhlaup involving potholes on Black Rapids Glacier, Alaska Range, Alaska, U.S.A. J. Glaciol., 36(122), 125-126.

Thorarinsson, S. 1969. Glacier surges in Iceland, with special reference to the surges of Brúarjökull. Can. F. Earth Sci., 6(4), 875-882.

Wilbur, S. 1988. Surging versus nonsurging glaciers: a comparison using morphometry and balance. (M.S. thesis, University of Alaska.)

The accuracy of references in the text and in this list is the responsibility of the authors, to whom queries should be addressed.

\section{APPENDIX}

\section{APPLICATION OF MASS CONTINUITY}

This Appendix provides the background for the results given in section V. Since the cross-sectional area $A(x)$ in Equation (1) is not known, it is approximated by defining an area shape factor $f$ by

$$
A(x)=f(x) W(x) H(x)
$$

where $H$ is the known center-line thickness of the ice, $W$ is the known width, and for all positions $x$ we use the value $f=0.66$ calculated from the cross-section measured near point X. Equations (1) and (Al) give

$$
Q=g f W H D
$$

in which $Q$ is the volume of ice transported in the main branch. The meaning of these equations is complicated by the fact that the displacement $D$ is large; for example, the fractional change in thickness $H$ at a given point may be appreciable during the surge. For this reason, we use for $H$ the average of its values before and after the surge.

The next step is to note that the volume transport $Q$ at $x$ is equal to the volume increase of the glacier below that point, at least if volume changes due to crevassing are neglected:

$$
Q(x)=\int_{x_{\text {lower }}}^{x}(\Delta H) W \mathrm{~d} x^{\prime}-T(x) .
$$

$x_{\text {lower }}$ is the longitudinal coordinate of the lower limit of the surge. $\Delta H$ is the increase in ice thickness averaged across the glacier; we will make the approximation that it is the same as the measured center-line thickness change. The integration is carried out over the main trunk of the glacier. The volume change of the tributaries is represented by the term $T(x)$. For a single, narrow tributary, $T(x)$ would approximate a step function at the confluence with the main trunk. $T(x)$ has the following limits:

$$
\begin{array}{ll}
T(x)=0 & \text { (below the tributaries) } \\
T(x)=Q_{\mathrm{T}} & \text { (above the tributaries) }
\end{array}
$$

in which $Q_{\mathrm{T}}$ is positive and equal to the decrease in volume of the tributaries during the surge. (In actuality, $T(x)$ will be some function of $x$ connecting these two limits.)

Below the tributaries, where $T(x)=0$ (Equation (A4a)), Equation (A3) determines $Q$, from which Equation (A2) determines $g$ (Fig. 9). At points farther up-glacier, we fix $g$ at 0.90 , its value below the tributaries. Equation (A2) then determines $Q$ up to point $\mathrm{X}$ at $24.2 \mathrm{~km}$, the highest point at which elevation change at the center of the glacier was determined. $T(x)$ then follows from Equation (A3) (Fig. 9). ( $T(x)$ is somewhat arbitrary where the tributaries enter because it depends upon the definition of the width of the main trunk and the meaning of the shape factor there.) Next, $Q_{\mathrm{T}}$ can be found by evaluating Equation (A3) at some point above the tributaries, such as point $\mathrm{X}$, so that by Equation (A4b) one can substitute $T(x)=Q_{\mathrm{T}}$. Solving the resulting version of Equation (3) gives $Q_{\mathrm{T}} \cong 750 \times$ $10^{6} \mathrm{~m}^{3}$. Using this value of $Q_{\mathrm{T}}$ in Equation (A3) for all $x$ above $\mathrm{X}$, one can solve for $Q$ above point $\mathrm{X}$ (dotted line in Figure 9). The displacement $D$ above the highest measured point at $26.3 \mathrm{~km}$ follows from Equation (A2) (dotted line in Figure 6). The uncertainty in these values for $Q$ and $D$ is large because above $\mathrm{X}$ the changes in elevation upon which they depend were measured at the valley walls only, and may not be as representative of average thickness change as values measured at the center of the glacier. 